UDC 821.161.1.09 Dostoevskij F. M. https://doi.org/10.18485/ms_zmss.2021.99.7

\title{
Вадим Школьников
}

НИУ Высшая школа экономики, Санкт-Петербург

vshkolnikov@hse.ru

Vadim Shkolnikov

HSE University, St. Petersburg

vshkolnikov@hse.ru

\section{ДОСТОЕВСКИЙ И ПИСАРЕВ: ДВЕ ПРЕКРАСНЫЕ ДУШИ В ЛИТЕРАТУРНОМ ПОЛЕ}

\section{DOSTOEVSKY AND PISAREV: TWO BEAUTIFUL SOULS IN THE LITERARY FIELD}

Статья разрабатывает новую точку зрения на идеологический антагонизм между Достоевским и радикальным критиком Д. И. Писаревым, антагонизм, отражающий более фундаментальный раскол среди интеллигенции XIX века - так называемой «совести русского общества». Опираясь на гегельянскую тематику совести и прекрасной души из Феноменологии духа (которая сыграла важную роль в возникновении интеллигенции), анализ рассматривает полемику Достоевского и Писарева как следствие неизбежного диссонанса внутри самой логики совести, который Гегель драматизирует как столкновение двух членов сообщества добросовестных: столкновение одной «прекрасной души», которая действует, и другой «прекрасной души», которая не действует, а только судит. Во время полемики Достоевский и Писарев похожи на эти две прекрасные души, не подозревающие, что они воплощают две необходимые стороны совести. В то же время, учитывая, что этот конфликт осуществлялся в двух толстых журналах, конкурирующих на открытом рынке, анализ также ссылается на социологическую концепцию «литературного поля» Бурдье и его идею «символического капитала». С этой точки зрения Достоевский и Писарев воплощают два диаметрально противоположных способа накопления символического капитала. Хотя конфликт этих двух прекрасных душ временно приводит к застою среди интеллигенции, в конечном итоге он преобразует характер деятельной совести.

Ключевые слова: Достоевский, Д. И. Писарев, Гегель, Пьер Бурдье, интеллигенция, совесть, прекрасная душа, нигилизм.

This paper develops a new perspective on the ideological antagonism between Dostoevsky and the radical critic Dmitri Pisarev, as representative of a more fundamental rift within the nineteenth-century intelligentsia - the so-called "conscience of Russian society." Drawing on Hegel's thematics of conscience and the beautiful soul from the Phenomenology of Spirit (which played a vital role in the emergence of the intelligentsia), the analysis links Dostoevsky's polemic with Pisarev to an unavoidable dis- 
sonance within the inner logic of conscience, which Hegel dramatizes as a clash between two members of the conscientious community: a "beautiful soul" that acts and another "beautiful soul" that never acts, but only judges. Throughout their polemic Dostoevsky and Pisarev resemble these two "beautiful souls," who do not realize that they represent two essential sides of conscience. At the same time, given that this conflict pitted two rival journals operating within an open literary market, the analysis also draws on Bourdieu's sociological conception of the "literary field" and his notion of "symbolic capital." From this perspective, Dostoevsky and Pisarev exemplify two diametrical opposed approaches to accumulating symbolic capital. Although the conflict between these two beautiful souls initially leads to an impasse among the intelligentsia, it will eventually transform the nature of conscientious action.

Key words: Dostoevsky, D. I. Pisarev, Hegel, Pierre Bourdieu, intelligentsia, conscience, beautiful soul, nihilism

Данная статья о двух «прекрасных душах»-Ф. М. Достоевском и Д. И. Писареве - исходит из более широкой исследовательской работы, посвященной Феноменологии духа Гегеля в историческом развитии русской интеллигенции XIX века. В мемуарах Былое и думы Александр Герцен, один из главных представителей раннего русского гегельянства, утверждает, что «Человек, не переживший “Феноменологии” Гегеля [...], не перешедший через этот горн и этот закал, не полон, не современен» (Герцен 1956: 23). В этом смысле моя цель - проанализировать именно этот процесс «переживания». Начиная с первого ознакомления с Феноменологией в конце 1830-х годов, формировавшаяся интеллигенция (та группа, которая впоследствии будет называться «интеллигенцией») переживает, испытывает, нечто похожее на сам феноменологический нарратив Гегеля: это сложный процесс развития самосознания, путем проб и ошибок, в котором сознание продвигается вперед за счет собственных внутренних противоречий.

В этом контексте особенно важен образ «прекрасной души» из Феноменологии. В. Г. Белинский, М. А. Бакунин и другие члены философского кружка Н. В. Станкевича впервые ввели слово «прекраснодушие» (калька с немецкого Schönseeligkeit) в русский язык, именно в смысле того отрицательного, ироничного психологического портрета, который создал Гегель (Школьников 2019; Виноградов 1999: 549-552). Из-за своего стремления к моральному совершенству, прекрасная душа впадает в томительное, абстрактное состояние: она лишается действительности (Гегель 2000: 341). Члены кружка Станкевича отождествляли себя с этим персонажем Гегеля, чувствуя, что они переживают тот же нарратив. Они боролись против собственного прекраснодушия, опираясь на философию Гегеля как на прагматичное руководство в стремлении «стать действительным человеком» (стать «полным» и «современным», по вышеупомянутому выражению Герцена) (Shkolnikov 2018). В результате эта проблематика прекрасной души - ключ к пониманию интеллектуального развития кружка, особенно развития реализма Белинского, и все 
это помогает объяснить, почему эти ранние русские гегельянцы также являются главными прототипами будущей интеллигенции (после того как это слово войдет в обиход в 1860 -е годы) 1 .

Для истории интеллигенции значительно, что прекрасная душа Гегеля принадлежит к проблематике «совести» (Gewissen). В Феноменологии совесть появляется только на очень высоком уровне развития сознания: это непосредственное предчувствие полного философского самосознания (absolute Wissen). Но логика совести также проблематична, подрывающая саму себя, что приводит к ловушке прекрасной души. Данная тематика позволяет нам переосмыслить распространенное, хотя смутное, определение интеллигенция XIX века как «совесть русского общества» ${ }^{2}$. С гегельянской точки зрения это не просто идеализированная похвала, а начало теоретической проблемы.

Нужно уточнить, что Гегеля интересует совесть преимущественно как моральная самоуверенность, непогрешимое сознание своей правоты, а не как чувство вины. Итак, совесть - совершенно автономный, самооправдывающий моральный авторитет, в принципе свободный от всех социально установленных законов (Гегель 2000: 323, 325-326, 327). Причем, в отличии от кантовского морализма (против которого Гегель полемизирует) совесть проявляется в деятельности (Там же: 322-325). Но чтобы стать объективной, такая совесть должна быть признана другими (Там же: 326). Поэтому гегельянская совесть появляется на исторической сцене в форме сообщества добросовестных людей. В конечном итоге каждый член такого сообщества является прекрасной душой, но из-за этого сообщество шатко, нестабильно.

Я предлагаю, что можно рассмотреть русскую интеллигенцию, развиваясь из философских кружков николаевской эпохи, как новую, непредвиденную вариацию той европейской традиции сообщества совести, на которую ссылается Гегель ${ }^{3}$. Таким образом, возникает возможность переосмыслить основные конфликты в бурной и кровавой истории интеллигенции как следствие внутренних, логических проблем, апорий, совести. Нужно подчеркнуть «кровавой», потому что та же история интеллигенции и совести приведет к тактикам революционного терроризма.

1 О происхождении слова «интеллигенция» см. (Успенский 1999: 7). Хотя есть разные подходы к периодизации истории интеллигенции, по Лотману «расцвет» интеллигенции относится к периоду от Белинского до публикации альманаха Вехи (1909) (Лотман 1999: 126).

2 Например: «Сила русской интеллигенции - не в intellectus'e, не в уме, а в сердце и совести. Сердце и совесть ее почти всегда на правом пути; ум часто блуждает. Сердце и совесть свободны, ум связан. Сердце и совесть бесстрашны и 'радикальны'» (Мережковский 1914: 34).

3 Обычно предполагается, что общины пиетистов служили прототипом для Гегеля (Kalkavage 2007: 345). 
Итак, в кульминации одной из главных концептуальных линий Феноменологии (в конце длинной части под заглавием «Дух») Гегель драматизирует логическую нестабильность совести как конфликт двух членов сообщества, двух прекрасных душ (Гегель 2000: 336-342). Одна прекрасная душа олицетворяет спонтанный, деятельный принцип совести: это прекрасная душа деятель. Другая прекрасная душа, озабоченная своим внутренним совершенством, не действует, а только судит поступки других: это прекрасная душа судья. В антагонизме этих двух прекрасных душ взаимное признание, на котором основана совесть, разлагается, и они обвиняют друг друга в лицемерии. Причем, сама логика совести приводит к этому тупику, когда выглядит, что деятельность согласна с совестью - невозможна. Это будет продолжаться, пока каждый из прекрасных душ не увидит себя в другом и поймет, что они составляют две стороны одного целого.

В истории русской интеллигенции постоянно разыгрывается подобная драма. Начинается это с Белинского и Бакунина во время известной полемической переписке (особенно в 1837-1838 гг.). Каждый осуждал прекраснодушие другого и одновременно проклинал собственное прекраснодушие. Как Белинский впоследствии рассказывал: «Нападая на прекраснодушие, [мы] сами служили самым забавным примером его» (Белинский 1956: 384). Можно также рассмотреть типологию, разработанную в эссе Тургенева «Гамлет и Дон Кихот» (1860), как вариацию на тему двух прекрасных душ (Гамлет - судья; Дон Кихот - деятель). Для данной статьи важно, что рассказчик Записок из подполья, высказываясь о «деятелях» с призрением, имплицитно ставит себя в положение прекрасной души судьи. (В дальнейшей истории можно заметить, что Л. Н. Толстой, изображая Наполеона в Войне и мир, ведет себя как прекрасная душа судья, пытаясь разоблачить исторического деятеля. Однако в романе Воскресение Толстой переходит на другую сторону, смело развивая идеологию деятельной совести, в соответствии с собственным отказом от аристократического образа жизни по нравственным убеждениям.)

В результате, эта гегельянская тематика дает нам новую точку зрения на самый известный раскол в истории интеллигенции: конфликт между людьми 1840-х годов, оставшиеся поклонниками «прекрасного», и молодым поколением 1860 -х, которое как известно пропагандировало «дело». То, что в русской истории проявляется как конфликт двух поколений, старого и нового, с другой точки зрения отражает фундаментальное разногласие, уже вложенное в синхронную структуру совести. (Также, по-гегельянски можно сказать, что это два «момента» диалектической логики совести.)

Как представители этого интеллигентского конфликта, Достоевский и Писарев ведут себя как две прекрасные души, которые не видят, что они составляют две необходимые стороны совести, без которых община — интеллигенция - не могла бы существовать. 
Писарев, занимавший должность главного критика журнала $P y c$ ское слово с 1861 г., начал привлекать внимание Достоевского в период издания журнала Время. В статье 1862 г. сотрудник Времени и идеологический соратник Достоевского Н. Н. Страхов определил Писарева самым крайним представителем идеологии молодых «нигилистов»: «Самое новое, самое выразительное проявление нашей современной литературы <...> Г. Чернышевский смел и откровенен, г. Писарев еще смелее и откровеннее; г. Чернышевский есть основание и начало, г. Писарев — вывод и конец» (Страхов 1890: 102-103). Джозеф Франк выделяет рассуждения Писарева о Базарове из Отщов и детей Тургенева («Ничто, кроме личного вкуса, не мешает им убивать и грабить, и ничто, кроме личного вкуса, не побуждает людей подобного закала делать открытия в области наук и общественной жизни») как главный прототип «нигилизма» Раскольникова, который Достоевский стремится разоблачить в Преступлении и наказании (Писарев 1955: 10; Frank 1986: 175).

Значительно, что в отличии от спора о нигилизме в Omuax u demяx Тургенева, полемика между Достоевским и Писаревым зарождается в контексте двух конкурирующих журналов, при рыночных условиях журнального бизнеса - иначе говоря, в социологических рамках «литературного поля», по определению Пьера Бурдье (Бурдье 2005). Вообще, уровень развития литературного поля - связанное с ростом литературного рынка и профессионализацией писательского творчества - составляет важное различие между интеллектуальной культурой 1840 -х и 60 -х годов в России ${ }^{4}$. В эпоху философских кружков зародыши интеллигентского самосознания развивались в приватной сфере личных, дружеских отношений и только начинали выступать публично (например, в статьях Белинского). Термин «интеллигенция» становится возможным в 60-е годы, потому что эта группа к тому времени уже укоренилась как феномен публичной жизни, объединяющий людей, которые никогда не встречались; феномен признанный, как и «своими», так и «не своими». В этом главнейшую роль играл публичный дискурс интеллигенции, осуществленный преимущественно в толстых журналах на (относительно) открытом литературном рынке 5 . Сознание экономической обусловленности литературы и интеллигентского дискурса, следовательно, становится неизбежным в полемике двух прекрасных душ.

4 Начало профессионализации в русской литературе обычно ассоциируется с Пушкиным (см. Эйхенбаум 2001: 49-87). О Достоевском Уильям Тодд пишет: «Он был по-настоящему профессиональнылм писателем во всех смыслах этого слова; что жизнь его после ссылки была тесно связана со средствами массовой коммуникации, читательской аудиторией, общественной и благотворительной деятельностью» (Тодд 2002: 15).

5 Как пишет Лотман: «Интеллигент есть субъект специфического интеллигентского дискурса; (само)определение интеллигенции осуществляется в рамках этого дискурсивного пространства» (Лотман 1999: 122). 
Здесь я хочу подчеркнуть еще одно нестандартное определение русской интеллигенции. Типично попытки ответить на вопрос «Что такое интеллигенция?» начинаются с замечания, что интеллигенция похожа на социальный класс, но все-таки не является социальным классом (Malia 1960: 445-446). Грубо говоря, интеллигенция XIX века находилась «по средине», между высшей, правительственной аристократией и массой трудящегося народа - напоминая таким образом Западный «средний класс», буржуазию. Но в отличии от Западной буржуазии интеллигенция не объединялась экономическими интересами, экономической деятельностью. Итак, выходит, что интеллигенция - группа, которую нельзя определить социо-экономическими критериями. (Это стандартный взгляд.)

Однако я хочу добавить, что все это требовало активной борьбы. Нет людей, которые просто априори не подлежат социо-экономическому определению. Для укоренения интеллигентского самосознания и создание собственного «мифа», нужно было активно противостоять социоэкономическому определению и конструировать образ своей мнимой экономической независимости.

Я представляю этот процесс в духе теории Бурдье о возникновении «чистого искусства» в французском литературном поле второй половины XIX века. Писателям как Флоберу нужно было создать свою автономность, свою независимость от рыночных и политических условий литературного производства (Bourdieu 2005). Как было упомянуто выше, гегельянская совесть основана на полной моральной автономии, и чтобы реализовать себя как некое сообщество совести, русской интеллигенции XIX века нужно было отстоять полную независимость своих моральных суждений. Но такая моральная независимость также требовала экономической независимости: интеллигент не мог представлять, что он пишет ради заработка или по приказу рыночных условий. Как выражается Подпольный человек Достоевского: «Вдруг представится горизонт соответственной деятельности, благотворной, прекрасной и, главное, совсем готовой» (Достоевский 1973: 133). Несмотря на иронический контекст этого замечания, здесь есть нечто серьезное. Для интеллигенции, чтобы стать интеллигенцией, нужно было представить, конструировать, такую сферу «соответственной деятельности» - деятельность, которая руководилось только побуждениями совести, независимо от экономических соображений ${ }^{6}$.

6 Этот принцип согласен с наблюдениями Тодда, что в романах Достоевского после Бедных людей, «Персонажам начинает хватать на жизнь, а затем финансовые заботы и вовсе перестают играть в их судьбах существенную роль [...] Герои произведений зрелого Достоевского, в отличие от своего автора (каким он предстает в своих письмах), не помешаны на каждодневной борьбе за кусок хлеба на деле он по-прежнему прилагал огромные усилия, чтобы сохранить не только финансовую, но и творческую независимость и целостность, лавируя между консервативными и радикальными издани- 
Дело в том, что Достоевский и Писарев совершенно по-разному воображали свою экономическую автономность, этот базовый критерий интеллигентского самосознания. Концепция одного была совершенно неприемлема для другого, и это привело к краху взаимного признания и к расколу в общине добросовестных.

Нужно заметить, что денежный вопрос присутствовал с самого начала в интеллигентской драме прекраснодушия. Ведь полемическая переписка Белинского и Бакунина началась с известного спора об «аккуратности и гривенниках», и это, в сущности, был вопрос интеллигентского самосознания. Белинский жаловался, что пока он не справится с долгами и не улучшит свою финансовую ситуацию, он не сможет отдаться чисто интеллектуальной деятельности, изучению философии и т. д. (Белинский 1956: 170-172). С точки зрения Бакунина такие низкие меркантильные соображения компрометировали высокое нравственное назначение философского кружка, и он настаивал на полную свободу «духа». В какой-то степени, бакунинский упрек (упрек прекрасной души судьи) продолжал служить аксиомой для будущей интеллигенции. Однако сам Бакунин отстаивал свою экономическую независимость с помощью постоянных займов (что отразилось в тургеневском образе Рудина). Такой рудинский прототип экономической автономии уже не был приемлем для интеллигенции 1860 -х годов.

В более развитом литературном поле накопление «символического капитала» становится ключевой задачей для интеллигенции. По Бурдье развитое литературное поле разделяется на два «субполя»: «широкого» и «узкого» производства (Бурдье 2005). К субполю широкого производства принадлежит литература, созданная ради быстрого и наибольшего финансового успеха; такое литературное производство максимально подчинено текущим рыночным требованиям. В России с 1829 г. «Библиотека для чтения» являлась главным примером литературного журнала как чисто коммерческое предприятие (и очень успешное предприятие) ${ }^{7}$. Хотя можно говорить об успехе и популярности Достоевского и Писарева (в разной степени), они оба принадлежали к субполю узкого производства, в котором как раз господствует стремление к «автономии» от рынка и некая экономическая «инверсия» ${ }^{8}$. Вместо прямого финансового успеха здесь ценится «символический капитал», на котором может быть основан будущий престиж и авторитетность (статус «классики» и т. д.). Пренебрежение к рыночной экономике требуется как признак «серьез-

ями, между воинствующим национализмом и христианским народничеством» (Тодд 2002: 15, 36).

7 Исследователь Hilde Hoogenboom утверждает, что даже в «эпоху реализма» иностранная сентиментальная литература имела самый большой коммерческий успех (Hoogenboom 2015).

8 Как замечает Тодд: «В 1863 году, Достоевский подсчитает, что лишь каждый пятисотый русский имеет доступ к элитарной литературе» (Тодд 2002: 17). 
ных», «чисто художественных» стремлений, и изначальный рыночный неуспех может способствовать накоплению символического капитала.

Итак, статус Достоевского и Писарева в истории интеллигенции, их вклад в постоянно развивающуюся парадигму добросовестной интеллигентской деятельности, основан на субстрате экономического поведения. Чтобы удержать интеллигентский дискурс в литературном поле, нужно было: 1) проявить независимость от рыночных требований, отделяя себя от субполя широкого производства, и 2) накопить достаточный символический капитал. Достоевский и Писарев воплощают два диаметрально противоположных способов накопления символического капитала, и на этом основан их антагонизм как два представителя сообщества прекрасных душ.

$$
* * *
$$

Удивительно, на сколько Писарев опирается на экономические и особенно капиталистические модели в своей программной статье «Реалисты». В целом можно рассматривать статью как манифест прекрасной души деятеля, например, когда Писарев утверждает: «В настоящее время всего необходимее превращать чувствительных тунеядцев в мыслящих работников» (Писарев 1956а: 74). В то же время, экономическое мышление пронизывает, обуславливает само определение реализма, и, оказывается, «строгий и последовательный реализм» есть не что иное, как «экономия умственных сил» (Там же: 11). Реализм указывает, какой деятельностью стоит или не стоит заниматься. Причем, ценность здесь определяется по аналогии с капиталистическим предприятием: «Реалист - расчетливый акционер, пустивший в оборот все свое состояние и всеми силами служащий делу компании, для увеличения собственного дивиденда. <..> умственный капитал должен приносить обществу хорошие проценты» (Там же: 67).

Однако эти экономические метафоры - только метафоры. Иначе нужно было бы просто заниматься предпринимательством, и Писарев помог бы породить молодое поколение капиталистов, а не нигилистов. К тому же, капиталистические метафоры Писарева описывают только производство и накопление, но фактически отсутствует личное потребление. Именно таким образом интеллигент-реалист не подчиняется экономической нужде. Вообще, пресловутая идеология «разумного эгоизма» почти не опирается на описание личной (потребительской) выгоды. Поэтому Писарев утверждает:

Вполне расчетливый эгоизм совершенно совпадает с результатами самого сознательного человеколюбия. Но, сознавая важное и высокое значение своего личного труда, видя в этом труде свою неразрывную связь с миллионами других мыслящих существ, трудящаяся личность еще 
сильнее привязывается к своей деятельности, еще смелее развертывает свои способности и, ясно понимая законность своих стремлений, становится более счастливою, то есть более независимою от тех тяжелых ощущений, которые порождаются мелкими неудачами (Там же: 64).

Само счастье интеллигента - и, более того, сознание «законности» своих стремлений, их «высокого значения» - все это основано на том, как деятельность связывает его с другими мыслящими существами. Это чувство общности (хотя «миллионы» - наверняка, преувеличение) гарантирует независимость интеллигента от внешних условий, удачи или неудачи.

В конечном итоге вся эта идеология сильно опирается на аскетические ценности и на квази-протестантскую трудовую этику: «Да, жизнь есть постоянный труд» (Писарев 1956b: 117). Труд здесь воспринимается как чисто моральная ценность, а не как способ добывания личной экономической выгоды. Для Писарева вся сила личности Базарова основана на том, что он вышел из «школы труда и лишений» (Писарев 1955: 9).

Нужно еще учитывать, что статья «Реалисты», как и другие важные тексты, была написана Писаревым во время заключения в Петропавловской крепости (июль 1862 - ноябрь 1866). Кажется, в такой обстановке было еще более свойственно отдаться аскетическому менталитету. Писарев даже отказался от внешней финансовой поддержки и помощи Литературного фонда (Быховский 1936: 655). Важно, что «Популярность Писарева, в это время достигает апогея. Он становится поистине "властителем дум" молодого поколения разночинной интеллигенции этой эпохи» (Там же: 663). Писареву удалось значительно увеличить свой «символический капитал» (основу культурной авторитетности), представляя интеллигентскую, добросовестную деятельность как тихий, постоянный, самоотверженный труд.

$$
* * *
$$

Мне кажется, для Достоевского была неприемлема именно эта идея, что жизнь - постоянный труд. Он не мог основать свою интеллектуальную деятельность и свою личность вообще на аналогии терпеливого, аскетического трудолюбия. Возможно, именно с этой точки зрения нужно понимать известный протест Подпольного человека: «Стою я... за свой каприз и за то, чтоб он был мне гарантирован <..> свой собственный, хотя бы самый дикий каприз <..> чтоб иметь право пожелать себе даже и глупейшего» (Достоевский 1973: 119, 113, 115). Хотя рассказчик Записок из подолья ссылается на образ будущего «Хрустального дворца», где каждая выгода будет заранее математически вычислена («вроде таблицы логарифмов, до 108 000»), нужно предполагать, что предсказания о далеком будущем не я являются единственным поводом для конфликта 
между Достоевским и нигилистами: также важен вопрос о «сегодняшних» (для Достоевского) жизненных условий (Там же: 113). Поэтому, «дикий каприз» Подпольного человека и «право пожелать себе даже и глупейшего» можно толковать как протест против писаревской парадигмы умеренного, скромного труда, и как непокорность по отношению к законам расчетливой продуктивности (а не «законам природы»).

К тому же, мы можем сказать, как Достоевский на практике осуществлял свой «самый дикий каприз», свое «право пожелать себе даже и глупейшего». Кажется, эти слова вполне описывают известную страсть Достоевского к азартным играм, к рулетке, и те бедствия, которые он вызывал своими неизбежными проигрышами. Зигмунд Фрейд видел в игре Достоевского «очевидный припадок патологической страсти <..> Он никогда не успокаивался, пока не терял все» (Фрейд 1995: 292). Однако я хочу подчеркнуть, что, помимо патологической точки зрения, здесь выражается отчетливая, закономерная схема экономического поведения, которая резко противостоит экономической схеме Писарева. В побуждении рисковать все и выстрадать любые потери видно некое притязание на экономическую свободу. Конечно, Достоевский писал отчасти из-за экономической нужды, но возможно, его поведение как игрок укрепляло хотя бы мнимое ощущение, что в интеллектуальной деятельности он также стоял выше экономической расчетливости.

В Записках из подолья описано психологическое состояние, наверняка похожее на типичный опыт самого Достоевского после очередного ужасного проигрыша. Как рассказывает Подпольный человек:

...до того доходил, что ощущал какое-то тайное, ненормальное, подленькое наслажденьице возвращаться, бывало, в иную гадчайшую петербургскую ночь к себе в угол и усиленно сознавать, что вот и сегодня сделал опять гадость, что сделанного опять-таки никак не воротишь, и внутренно, тайно, грызть, грызть себя за это зубами, пилить и сосать себя до того, что горечь обращалась наконец в какую-то позорную, проклятую сладость и наконец — в решительное, серьезное наслаждение! <..> наслаждение было тут именно от слишком яркого сознания своего унижения; <..> в отчаянии-то и бывают самые жгучие наслаждения, особенно когда уж очень сильно сознаешь безвыходность своего положения (Достоевский 1973: 102, 103).

В дневниках второй жены Достоевского, Анны Григорьевны, Фрейд обнаруживает похожий психологический цикл, когда Достоевский как будто наслаждался, утопая в чувстве собственной вины и безвыходности своего положения:

Игра была для него также средством самонаказания. Несчетное количество раз давал он молодой жене слово или слово чести больше не играть или больше не играть в этот день и, как она рассказывает, почти всегда 
нарушал свое обещание. Если проигрышами он доводил себя и ее до крайне бедственного положения, это служило для него вторым патологическим удовлетворением. Он получал возможность перед нею поносить и унижать себя... (Фрейд 1995: 292).

Причем, Фрейд замечает, что этот цикл проигрышей и самоунижения приводил к повышенной авторской продуктивности (Там же). В Записках из подолья мы видим, более того, как эта психологическая перверсия взаимосвязана со всей философией «свободы» Подпольного человека. Наслаждение в собственном унижении не является целью в себе, но это крайнее, лиминальное состояние указывает на конечную цель. В морально-эстетической системе Достоевского, полная утрата, потеря, своей стоимости как человек нужна, чтобы инициировать процесс воскресения и раскрыть истинный идеал красоты.

Интересно, что в своем анализе Преступления и наказания Писарев как раз подчеркивает ту тенденцию в рассуждениях Раскольникова, которая позволяет ему «ненавидеть упорный и неблагодарный труд и относиться с любовью и уважением к мысли о быстрой и легкой наживе $<. .>$ Всю свою теорию Раскольников построил исключительно для того, чтобы оправдать в собственных глазах мысль о быстрой и легкой наживе» (Писарев 1956c: 357-358). С этой точки зрения Раскольников напоминает игрока, который, презирая прозаический труд, готов рискнуть все сразу. Суть интерпретации Писарева в том, что Раскольников понял бы абсурдность своей теории, если бы он аккуратнее обдумал, принесет ли убийство настоящую выгоду ему, его матери, его сестре. Однако именно такой расчет выгоды совершенно не свойственный характеру Раскольникова. Вся диалектика преступления, раскаяния и возрождения, через которую он проходит, обусловлена отказом от расчетливости (как видно каждый раз, когда Раскольникову попадаются деньги).

$$
* * *
$$

Можно заключить, что Достоевского не устраивает экономическая парадигма Писарева именно по эстетическим причинам: из-за отсутствия прекрасного. Писарев ведь настаивает: «Эстетика и реализм действительно находятся в непримиримой вражде между собою, и реализм должен радикально истребить эстетику, которая в настоящее время отравляет и обессмысливает все отрасли нашей научной деятельности» (Писарев 1956а: 58). Писарев также развивает принцип «разрушение эстетики» в статье, посвященной десятилетию магистерской диссертации Чернышевского, «Эстетические отношения искусства к действительности» (Писарев 1956b). Рассуждения Чернышевского об эстетике сосредоточены на Эстетике Гегеля (хотя он опирается на пересказ Фридриха Фишера), и важно, что Чернышевский пытается разоблачить 
гегельянское определение прекрасного как совершенное соответствие внешней формы и идейного содержания (Чернышевский 1949: 6-8). Кажется, Писарев подхватывает эту точку зрения, и в отличии от Достоевского, который не приемлет экономию расчетливости, для Писарева именно экономия прекрасного - совершенное равновесие формы и содержания - является чем-то обременительным, от чего нужно освободиться. Заботиться об экономии формы и содержания - значит нарушать экономию умственных сил. Причем, эти выводы вполне закономерны для прекрасной души деятеля из Феноменологии. Деятель, поступая согласно с совестью, может не бояться загрязниться. Красота и особенно эстетический морализм - удел прекрасной души судьи.

Известно, что Достоевский воспринимал образ Иисуса Христа как «идеал красоты человеческой»: «его чудесная и чудотворная красота» утверждается в Дневнике писателя (Достоевский 1980b: 10). Это можно понять в гегельянских терминах: внешняя, телесная форма Иисуса идеально соответствует внутренней, божественной идеи для Достоевского. Этот эстетизм, однако, имеет значительные последствия для сообщества совести, то есть, для нравственной оценке поступков.

Отказ Писарева от эстетики и вся идеология разумного эгоизма имеет эффект демистификации совести. Например, молодой Бакунин писал своей сестре: «Я чувствую в своем внутреннем существе нечто такое, что никогда не обманет меня, что не зависит ни от чего внешнего. Я чувствую в себе бога» (Бакунин 1934: 235). В сущности, Бакунин здесь просто выражает фундаментальную логику совести. Но заменяя эту восторженность доктриной разумного эгоизма, люди $60-$ х гг. переосмыслили совесть как нечто более прозаичное. В результате, чтобы поступать согласно с совестью, как пишет Писарев, «не надо быть ни гениальным мыслителем, ни героем или фанатиком человеколюбия» (Писарев 1956а: 65-66).

Похоже, что Достоевский остался ближе к менталитету молодого Бакунина, так как нравственность для Достоевского опирается на парадигму грандиозного акта самопожертвования. Объясняя свой идеал в эссе «Социализм и христианство», он пишет: «Достигнуть полного могущества сознания и развития, вполне сознать свое я — и отдать это всё самовольно для всех <..> быть властелином и хозяином даже себя самого, своего я, пожертвовать этим я, отдать его - всем. В этой идее есть нечто неотразимо прекрасное» (Достоевский 1980а: 192). Однако нужно добавить, что этот грандиозный, драматический акт подражания Христу характерно следует только после крайнего чувства вины и унижения, типа того, что описывает Подпольный человек. Во Сне смешного человека главный персонаж пытается совершить великий акт самопожертвования, принимая распятие ради жителей неизвестной планеты но только после того, как он осознает свою вину за их падение: «Я про- 
стирал к ним руки, в отчаянии обвиняя, проклиная и презирая себя. Я говорил им, что все это сделал я, я один, что это я им принес разврат, заразу и ложь! Я умолял их, чтоб они распяли меня на кресте, <... я хотел принять от них муки, я жаждал мук» (Достоевский 1983: 117). В этой психологии мы узнаем и мазохизм Подпольного человека и наслаждение, которое сам Достоевский испытывал от собственного унижения после неразумного проигрыша. Смешной человек воображает, что спасение или падение всего человечества зависит от него одного, и, следовательно, он воплощает образ нравственного деяния как внезапный, театральный, почти безумный акт самопожертвования, мало похожий на самоотверженный труд Писарева.

Для прекрасной души судьи в Феноменологии именно требования «прекрасного» и «безусловного» становятся поводом для непризнания деятеля. Опираясь на свой эстетический морализм, судья никогда не признает добросовестность чужих поступков (Гегель 2000: 339). Деятель всегда грешник, всегда лицемер, потому что его поступки, несущие «клеймо определенности», всегда грязны по сравнению с идеалом красоты (Там же: 329).

В конечном итоге гегельянский нарратив приводит к примирению двух прекрасных душ, и таким образом осуществляется новая, интерсубъективная община - «“я”, которое есть “мы”, и “мы”, которое есть “я”» (Там же: 97). Однако Достоевский фактически принимает невозможность взаимного признания как аксиому. Нет взаимного признания во Сне смешного человека, так как главный персонаж и жители планеты, ради которых он хочет пожертвовать собой, совершенно не понимают друг друга. В произведениях Достоевского имплицитно изображенное сообщество совести характерно страдает от раскола и отсутствия взаимного признания - характерно находится в состоянии кризиса.

Нужно признать, что в контексте литературного поля публичный спор между партиями Достоевского и Писарева помог обеим сторонам: они таким образом укоренились в субполе узкого производства и приобрели достаточный символический капитал. Однако вне литературной саморефлексии этот конфликт действительно являлся моментом застоя для интеллигенции как действующая совесть.

Не признавая, осуждая деятеля, прекрасная душа судья «упорствует», как пишет Гегель, «в своенравном бессилии»: ей «недостает <..> силы сделаться вещью и выдержать бытие. Он[а] живет в страхе, боясь запятнать великолепие своего 'внутреннего' поступками и наличным бытием; и дабы сохранить чистоту своего сердца, он[а] избегает соприкосновения с действительностью» (Там же: 335-336). В этом описании прекрасной души, которая уже совсем не прекрасная, мы узнаем то «бесхарактерное», страдающее состояние, в котором находится Подпольный человек, и которое он считает уделом любого умного человека XIX века: 
«Да-с, умный человек девятнадцатого столетия должен и нравственно обязан быть существом по преимуществу бесхарактерным; человек же с характером, деятель, - существом по преимуществу ограниченным» (Достоевский 1973: 100). В Подпольном человеке мы видим русского интеллигента, доведенного до состояния, когда нет надежды на взаимное признание и кажется, что нет возможности значительного поступка согласно с совестью.

Без взаимного признания то же самое происходит со стороны Базаровых, деятелей. Как воображает Писарев: «“Я не могу действовать теперь, - думает про себя каждый из этих новых людей, — не стану и пробовать” (Писарев 1955: 19). Писарев также замечает, что в Преступлении и наказании даже не возникает вопрос об оправдании поступка, убийства, Раскольникова совестью: если бы у Раскольникова была хоть малейшая вера, что его теория необыкновенных людей может дать ему нравственное право на убийство, нужно было бы объяснить эту логику другим (Писарев 1956c: 359-360). По Гегелю, человек поступающий согласно с совестью обязательно должен сказать это (Гегель 2000: 333). Поскольку Раскольников даже не пытается это сделать, он априори исключает свой поступок из сферы совести.

Подобные застои, кризисные моменты в истории интеллигенции, приводили к преобразованию совести, к изобретению новых форм деятельности по совести. (Такая логика и продвигает феноменологический нарратив Гегеля.) Враждующие стороны сообщества влияют друг на друга, пока взаимное признания опять не становится возможным. В конечном итоге русские интеллигенты-деятели сами приняли ту парадигму грандиозного, прекрасного самопожертвования, которую пропагандировал Достоевский. Хотя он сам этого не предвидел, это началось с теракта Веры Засулич.

\section{ЛИТЕРАТУРА}

Бакунин Михаил. Собрание сочинений и писем: 1828-1876. В 4 т. Т. 1. Москва: Издательство всесоюзного общества политкаторжан и ссыльно-поселенцев, 1934.

Белинский Виссарион. Письма, 1829-1840. Белинский Виссарион. Полное собрание сочинений. В 13 т. Т. 11. Москва: Академия наук СССР, 1956.

Бурдье Пьер. «Поле литературы»/ Перевод с франц. М. Гронаса. Бурдье Пьер. Социальное пространство: поля и практики/Отв. ред. Н. А. Шматко. Санкт-Петербург: Алетейя, 2005.

Быховский Наум. «Д. И. Писарев в Петропавловской крепости». Литературное наследство, 25-26. Москва: Журнально-газетное объединение, 1936: 655-679.

Виноградов Виктор. История слов. Москва: Росс. акад. наук, 1999.

Гегель Георг Вильгельм Фридрих. Феноменология духа / Перевод с нем. Г. Г. Шпета. Москва: Наука, 2000.

Герцен Александр. Былое и думы. Часть IV. Герцен Александр. Собрание сочинений. В 30 т. Т. 9. Москва: Академия наук СССР, 1956. 
Достоевский Федор. Записки из подполья. Достоевский Федор. Полное собрание сочинений. В 30 т. Т. 5. Ленинград: Наука, 1973.

Достоевский Федор. «Социализм и христианство». Достоевский Федор. Полное собрание сочинений. В 30 т. Т. 20. Ленинград: Наука, 1980а.

Достоевский Федор. Дневник Писателя. 1873. Достоевский Федор. Полное собрание сочинений. В 30 т. Т. 21. Ленинград: Наука, $1980 \mathrm{~b}$.

Достоевский Федор. Сон смешного человека. Достоевский Федор. Полное собрание сочинений. В 30 т. Т. 23. Ленинград: Наука, 1983.

Лотман Юрий. «Интеллигенция и свобода». Успенский Борис (ред.-сост.). Русская интеллигенция и западный интеллектуализм: История и типология. Москва: О.Г.И., 1999: 121-149.

Мережковский Дмитрий. «Грядущий Хам». Мережковский Дмитрий. Полное собрание сочинений. В 24 т. Т. 14. Москва: Типография И. Д. Сытина, 1914: 5-39.

Писарев Дмитрий. «Базаров». Писарев Дмитрий. Сочинения. В 4 т. Т. 2. Москва: Государственное издательство художественной литературы, 1955.

Писарев Дмитрий. «Реалисты». Писарев Дмитрий. Сочинения. В 4 т. Т. 3. Москва: Государственное издательство художественной литературы, 1956а.

Писарев Дмитрий. «Разрушение эстетики». Писарев Дмитрий. Сочинения. В 4 т. Т. 3. Москва: Государственное издательство художественной литературы, $1956 \mathrm{~b}$.

Писарев Дмитрий. «Борьба за жизнь». Писарев Дмитрий. Сочинения. В 4 т. Т. 4. Москва: Государственное издательство художественной литературы, $1956 \mathrm{c}$.

Страхов Николай. «Пример апатии (Письмо в редакцию “Времени” по поводу статьи Г. Антоновича “О почве”. Современник 1861, декабрь». Страхов Николай. Из истории литературного нигилизма 1861-1865: Письма Н. Косицы. Заметки летописиа, u np. Санкт-Петербург: Типография братьев Пантелеевых, 1890: 102-129.

Тодд Уильям. «Достоевский как профессиональный писатель: профессия, занятие, этика». Новое литературное обозрение 58/6 (2002): 15-43.

Успенский Борис. «Русская интеллигенция как специфический феномен русской культуры». Успенский Борис (ред.-сост.). Русская интеллигенция и западный интеллектуализм: История и типология. Москва: О.Г.И., 1999: 7-19.

Фрейд Зигмунд. «Достоевский и отцеубийство»/Перевод с нем. Додельцева Р. Ф. Додельцева, Долгова К. М. (ред.). Художник и фантазирование. Москва: Республика, 1995: 285-294.

Чернышевский Николай. Эстетические отношения искусства к действительности. Чернышевский Николай. Полное собрание сочинений. В 15 т. Т. 2. Москва: Государственное издательство художественной литературы, 1949: 5-92.

Школьников Вадим. «Историческая семантика 'прекраснодушия' в раннем русском гегельянстве». Кагарлицкий Юрий, Калугин Дмитрий, Маслов Борис (ред.). Понятия, идеи, конструкии: Очерки сравнительной исторической семантики. Москва: Новое литературное обозрение, 2019: 194-222.

Эйхенбаум Борис. Мой временник. Маршрут в бессмертие. Москва: Аграф, 2001.

Bourdieu Pierre. "Flaubert and the French Literary Field"/Trans. from French by Claud DuVerlie. Bourdieu Pierre. The Field of Cultural Production: Essays on Art and Literature / Ed. Randal Johnson. New York: Columbia U. Press, 2005.

Frank Joseph. Dostoevsky: The Stir of Liberation, 1860-1865. Princeton, NJ: Princeton U. Press, 1986.

Hoogenboom Hilde. "Sentimental Novels and Pushkin: European Literary Markets and Russian Readers". Slavic Review 74/3 (2015): 553-574.

Kalkavage, Peter. The Logic of Desire: An Introduction to Hegel's Phenomenology of Spirit. Philadelphia, PA: Paul Dry Books, 2007.

Malia Martin. "What Is the Intelligentsia?" Daedalus 89/3 (1960): 441-458.

Shkolnikov Vadim. "Stankevich, Bakunin, Belinsky, and the Phenomenology of Conscience: On the Founding Myth of the Russian Intelligentsia". Die Welt der Slaven. Internationale Halbjahresschrift für Slavistik 63/2 (2018): 334-363. 


\section{LITERATURE}

Bakunin Mihail. Sobranie sochinenij i pisem: 1828-1876. V 4 t. T. 1. Moskva: Izdatel'stvo vsesoyuznogo obshchestva politkatorzhan i ssyl'no-poselencev, 1934.

Belinskij Vissarion. Pis'ma. 1829-1840. Belinskij Vissarion. Polnoe sobranie sochinenij. V 13 t. T. 11. Moskva: Akad. nauk SSSR, 1956.

Bourdieu Pierre. "Flaubert and the French Literary Field"/Trans. from French by Claud DuVerlie. Bourdieu Pierre. The Field of Cultural Production: Essays on Art and Literature/ Ed. Randal Johnson. New York: Columbia U. Press, 2005.

Burd'e P'er. «Pole literatury»/ Perevod s franc. M. Gronasa. Burd'e P'er. Social'noe prostranstvo: polya i praktiki/Otv. red. N. A. SHmatko. Sankt-Peterburg.: Aletejya, 2005.

Byhovskij Naum. «D. I. Pisarev v Petropavlovskoj kreposti». Literaturnoe nasledstvo. 25-26. Moskva: Zjurnal'no-gazetnoe ob"edinenie, 1936: 655-679.

Chernyshevskij Nikolaj. Esteticheskie otnosheniya iskusstva k dejstvitel'nosti. Chernyshevskij Nikolaj. Polnoe sobranie sochinenij. V 15 t. T. 2. Moskva: Gosudarstvennoe izdatel'stvo hudozhestvennoj literatury, 1949: 5-92.

Dostoevskij Fedor. Zapiski iz podpol'ya. Dostoevskij Fedor. Polnoe sobranie sochinenij. V 30 t. T. 5. Leningrad: Nauka, 1973.

Dostoevskij Fedor. «Socializm i hristianstvo». Dostoevskij Fedor. Polnoe sobranie sochinenij. V 30 t. T. 20. Leningrad: Nauka, 1980a.

Dostoevskij Fedor. Dnevnik Pisatelya. 1873. Dostoevskij Fedor. Polnoe sobranie sochinenij. V 30 t. T. 21. Leningrad: Nauka, 1980b.

Dostoevskij Fedor. Son smeshnogo cheloveka. Dostoevskij Fedor. Polnoe sobranie sochinenij. V 30 t. T. 23. Leningrad: Nauka, 1983.

Ejhenbaum Boris. Moj vremennik. Marshrut v bessmertie. Moskva: Agraf, 2001.

Frank Joseph. Dostoevsky: The Stir of Liberation, 1860-1865. Princeton, NJ: Princeton U. Press, 1986.

Frejd 3igmund. «Dostoevskij i otceubijstvo»/Perevod s nem. Dodel'ceva R. F. Dodel'ceva, Dolgova K. M. (red.). Hudozhnik i fantazirovanie. Moskva: Respublika, 1995: 285-294.

Gegel' Georg Vil'gel'm Fridrih. Fenomenologiya duha/Perevod s nem. G. G. SHpeta. Moskva: Nauka, 2000.

Gercen Aleksandr. Byloe i dumy. Chast' IV. Gercen Aleksandr. Sobranie sochinenij. V 30 t. T. 9. Moskva: Akademiya nauk SSSR, 1956.

Hoogenboom Hilde. "Sentimental Novels and Pushkin: European Literary Markets and Russian Readers". Slavic Review 74/3 (2015): 553-574.

Kalkavage, Peter. The Logic of Desire: An Introduction to Hegel's Phenomenology of Spirit. Philadelphia, PA: Paul Dry Books, 2007.

Lotman Yurij. «Intelligenciya i svoboda». Uspenskij Boris (red.-sost.). Russkaya intelligenciya i zapadnyj intellektualizm: Istoriya i tipologiya. Moskva: O.G.I., 1999: 121-149.

Malia Martin. "What Is the Intelligentsia?" Daedalus 89/3 (1960): 441-458.

Merezhkovskij Dmitrij. «Gryadushchij Ham». Merezhkovskij Dmitrij. Polnoe sobranie sochinenij. V 24 t. T. 14. Moskva: Tipografiya I. D. Sytina, 1914: 5-39.

Pisarev Dmitrij. «Bazarov». Pisarev Dmitrij. Sochineniya. V 4 t. T. 2. Moskva: Gosudarstvennoe izdatel'stvo hudozhestvennoj literatury, 1955.

Pisarev Dmitrij. «Realisty». Pisarev Dmitrij. Sochineniya. V 4 t. T. 3. Moskva: Gosudarstvennoe izdatel'stvo hudozhestvennoj literatury, 1956a.

Pisarev Dmitrij. «Razrushenie estetiki». Pisarev Dmitrij. Sochineniya. V 4 t. T. 3. Moskva: Gosudarstvennoe izdatel'stvo hudozhestvennoj literatury, 1956b.

Pisarev Dmitrij. «Bor'ba za zhizn'». Pisarev Dmitrij. Sochineniya. V 4 t. T. 4. Moskva: Gosudarstvennoe izdatel'stvo hudozhestvennoj literatury, 1956s.

Shkolnikov Vadim. "Stankevich, Bakunin, Belinsky, and the Phenomenology of Conscience: On the Founding Myth of the Russian Intelligentsia". Die Welt der Slaven. Internationale Halbjahresschrift für Slavistik 63/2 (2018): 334-363. 
Shkol'nikov Vadim. «Istoricheskaya semantika 'prekrasnodushiya' v rannem russkom gegel'yanstve». Kagarlickij Yurij, Kalugin Dmitrij, Maslov Boris (red.). Ponyatiya, idei, konstrukcii: Ocherki sravnitel'noj istoricheskoj semantiki. Moskva: Novoe literaturnoe obozrenie, 2019: 194-222.

Strahov Nikolaj. «Primer Apatii (Pis'mo v redakciyu "Vremeni" po povodu stat'i G. Antonovicha "O pochve". Sovremennik 1861, dekabr'». Strahov Nikolaj. Iz istorii literaturnogo nigilizma 1861-1865: Pis'ma N. Kosicy. Zametki letopisca, i pr. Sankt-Peterburg: Tipografiya brat'ev Pantaleevyh, 1890: 102-129.

Todd Uil'yam. «Dostoevskij kak professional'nyj pisatel': professiya, zanyatie, etika». Novoe literaturnoe obozrenie 58/6 (2002): 15-43.

Uspenskij Boris. «Russkaya intelligenciya kak specificheskij fenomen russkoj kul'tury». Uspenskij Boris (red.-sost.). Russkaya intelligenciya i zapadnyj intellektualizm: Istoriya i tipologiya. Moskva: O.G.I., 1999: 7-19.

Vinogradov Viktor. Istoriya slov. Moskva: Rossijskaya akademiya nauk, 1999.

\section{Вадим Шкољников}

\section{ДОСТОЈЕВСКИ И ПИСАРЕВ: ДВЕ ПРЕЛЕПЕ ДУШЕ У КЬИЖЕВНОМ ПОЉУ}

\section{Резиме}

У раду се даје нови угао гледања на идеолошки антагонизам између Достојевског и радикалног критичара Д. И. Писарева; антагонизам који је одраз фундаменталнијег раскола унутар интелигенције XIX века — такозване „савести руског друштва“. Пола-

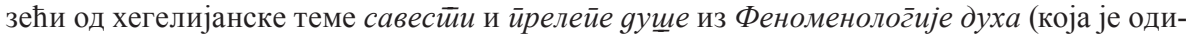
грала велику улогу у формирању интелигенције), у тексту се посматра полемика између Достојевског и Писарева као последица неизбежне дисонанце унутар саме логике савести, коју Хегел драматизује као судар два члана заједнице савесних: судар једне „прелепе душе“ која дела и друге „прелепе душе“ која не дела, већ само суди. У својој полемици Достојевски и Писарев су налик на ове две прелепе душе које и не сумњају да заправо отеловљују две нужне стране савести. Истовремено, имајући у виду да се овај конфликт распирује на страницама конкурентних часописа, анализа се ослања на социолошки концепт „књижевног поља“ Бурдјеа и на његову идеју „симболичког капитала“. С ове тачке гледишта, Достојевски и Писарев оваплоћују два дијаметрално супротна начина увећања симболичког капитала. Премда конфликт ове две прелепе душе привремено доводи до стагнациј унутар представника интелигенције, напослетку ипак мења карактер делатне савести.

Кључне речи: Достојевски, Д. И. Писарев, Хегел, Пјер Бурдје, интелигенција, савест, прелепа душа, нихилизам. 